(c) American Dairy Science Association, 2003.

\title{
Immune Response of Postpartum Dairy Cows Fed Flaxseed ${ }^{1}$
}

\author{
M. Lessard, N. Gagnon, and H. V. Petit \\ Dairy and Swine Research and Development Centre, \\ Agriculture and Agri-Food Canada, \\ Lennoxville, QC, Canada J1M 1 Z3
}

\begin{abstract}
Thirty Holstein cows were allotted at calving to 10 groups of three cows blocked for similar calving dates to determine the effects of dietary fatty acids on functional properties of immunocompetent cells in early lactation and at breeding. Cows were assigned at calving to one of three isonitrogenous, isoenergetic, and isolipidic supplements based on either calcium salts of palm oil, Megalac, micronized soybeans, or whole flaxseed. On the day of AI and $20 \mathrm{~d}$ later, cows were injected with ovalbumin to measure the antibody response. Blood samples were taken at different times after calving (d 5, 21, 42, and 105) and after AI (d 0, 10, 20, and 40) for quantification of serum progesterone, fatty acids, and prostaglandin $\mathrm{E}_{2}$ concentrations. Isolated peripheral blood mononuclear cells were cultured to evaluate the proliferative response to concanavalin $\mathrm{A}$ and in vitro productions of interferon- $\gamma$ and prostaglandin $\mathrm{E}_{2}$. In general, feeding flaxseed increased serum omega-3 fatty acids concentration compared with feeding Megalac or soybeans, which decreased the omega- 6 to omega3 fatty acids ratio. There was a significant diet $\times$ day interaction for the proliferative response of mononuclear cells after calving and AI, indicating that cell responses from cows fed flaxseed were transiently reduced compared with those fed Megalac and soybeans. Moreover, during the breeding period, serum progesterone concentration was significantly greater in cows fed flaxseed compared with those fed Megalac, whereas serum concentration of prostaglandin $\mathrm{E}_{2}$ was significantly lower in cows fed flaxseed than in those fed Megalac or soybeans. Dietary treatments had no effect on the antibody response to ovalbumin and on in vitro productions of interferon- $\gamma$ and prostaglandin $\mathrm{E}_{2}$. However, interferon- $\gamma$ and prostaglandin $\mathrm{E}_{2}$ were impaired in the first $3 \mathrm{wk}$ after parturition regardless of dietary treatment. These results suggest that changes in fatty acids, progesterone, and prostaglandins $\mathrm{E}_{2}$ concentrations in
\end{abstract}

Received September 13, 2002.

Accepted March 13, 2003.

Corresponding author: M. Lessard; e-mail: lessardm@agr.ca.

${ }^{1}$ Contribution no. 794 . serum due to dietary treatment and physiological status influenced systemic immunity as shown by reduced proliferative response. However, other mechanisms must be considered and are discussed to explain dietary effect on lymphocyte proliferative response to mitogenic stimulation and other immune functions.

(Key words: omega-3 fatty acids, immune response, dairy cow, flaxseed)

Abbreviation key: AS = autologous serum, BrdU = 5-bromo-2-deoxyuridine, ConA = concanavalin A, FA = fatty acids, FBS = fetal bovine serum, FLA = whole flaxseed, IFN- $\gamma=$ interferon- $\gamma, \mathbf{I L}=$ interleukin, LPS $=$ lipopolysaccharide, $\mathbf{O V A}=$ ovalbumin, $\mathbf{P}_{4}=$ progesterone, PBMC = peripheral blood mononuclear cells, PG $=$ prostaglandin, PUFA $=$ polyunsaturated fatty acids, RIA = radioimmunoassay, $\mathbf{S O Y}=$ micronized soybeans, TNF- $\alpha=$ tumor necrosis factor $-\alpha$.

\section{INTRODUCTION}

Dietary fatty acids (FA) can influence immunity through the production of cytokines and molecules involved in the regulation of immune responses. Omega3 and omega- 6 polyunsaturated FA (PUFA) are important immunomodulators of immune reactions (Miles and Calder, 1998). Human and animal studies have provided a great deal of evidence that feeding plant or fish oil rich in omega-3 FA alters the production of cytokines and the functional properties of macrophages, lymphocytes, and other immunocompetent cells (Calder et al., 2002; Yaqoob and Calder, 1995). One possible explanation of the mechanism is related to the synthesis of eicosanoids such as prostaglandins (PG) and leukotrienes. Omega-6 FA such as linoleic acid (C18:2n6) and omega-3 FA such as $\alpha$-linolenic acid (C18:3n3) lead to the formation of arachidonic acid and eicosapentaenoic acid, respectively. Both arachidonic acid and eicosapentaenoic acid are precursors of eicosanoids, but those that are synthesized from eicosapentaenoic acid do not have as strong biological activity as do those produced from arachidonic acid (Yaqoob and Calder, 1995). As a result, feeding plant or fish oil rich in omega3 PUFA generally reduces inflammatory reactions and production of interleukin (IL)-1, IL-6, and tumor necro- 
Table 1. Ingredient and chemical composition of experimental diets (DM basis except DM) ${ }^{1,2}$

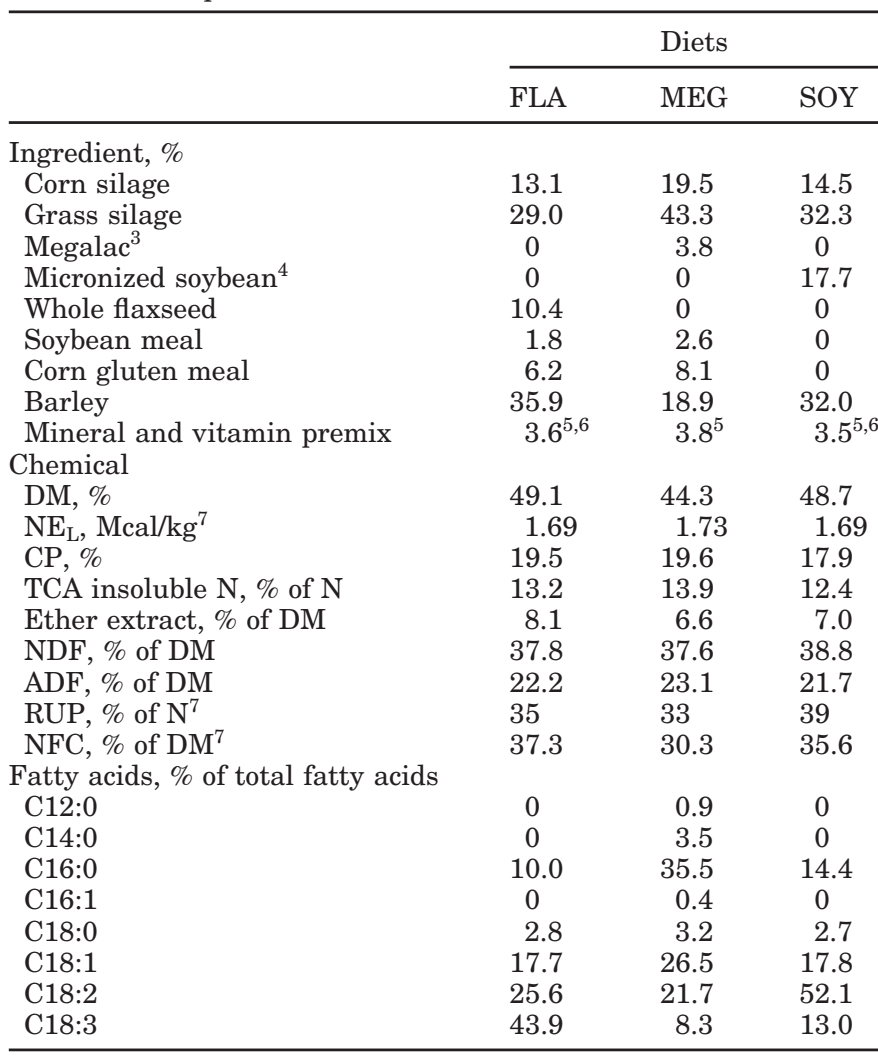

${ }^{1}$ Fat supplement based on FLA = whole flaxseed, MEG = Megalac, and $\mathrm{SOY}=$ micronized soybeans.

${ }^{2}$ Least squares means of 18 fornightly and nine monthly samples that were prepared by compositing weekly samples.

${ }^{3}$ Megalac calcium salts of palm oil (Church and Dwight Co., Inc., Princeton, NJ).

${ }^{4}$ MICRO-SOYA Elite 40\% CP (Semences Prograin Inc. St-Césaire, QC J0L 1T0, Canada).

${ }^{5}$ Contained $10.0 \% \mathrm{Ca}, 4.3 \% \mathrm{P}, 4.3 \% \mathrm{Mg}, 13.8 \% \mathrm{Na}, 1.8 \% \mathrm{~S}, 1.4 \%$ $\mathrm{K}, 7.5 \% \mathrm{NaCl}, 1760 \mathrm{mg} / \mathrm{kg}$ of Zn, $54 \mathrm{mg} / \mathrm{kg}$ of I, $32 \mathrm{mg} / \mathrm{kg}$ of Co, 1914 $\mathrm{mg} / \mathrm{kg}$ of $\mathrm{Mn}, 436 \mathrm{mg} / \mathrm{kg}$ of $\mathrm{Cu}, 2154 \mathrm{mg} / \mathrm{kg}$ of $\mathrm{Fe}, 15 \mathrm{mg} / \mathrm{kg}$ of Se, $197,200 \mathrm{IU} / \mathrm{kg}$ of vitamin A, 66,600 IU/kg of vitamin D, and $1030 \mathrm{IU} /$ $\mathrm{kg}$ of vitamin E.

${ }^{6} 250 \mathrm{~g} / \mathrm{d}$ of calcium carbonate $(38.0 \% \mathrm{Ca})$ was fed per cow.

${ }^{7}$ Calculated using published values of feed ingredients (NRC, 1989).

sis factor (TNF)- $\alpha$ in different animal species, including human. However, many contradictory observations have been reported (Calder et al., 2002).

In dairy cattle, whole flaxseed (FLA), which is a good source of omega-3 FA, have modified PG secretion and reproduction in dairy cows (Petit et al., 2002). This would suggest that flaxseed could also have an effect on other parameters influenced by secretion of PG such as immunity. Little is known on the effects of dietary FA on cellular and humoral immune responses in cows. A better understanding of the effects of FA on immune responses at different physiologic stages may help in determining nutritional conditions that optimize the
Table 2. Chemical composition of feed ingredients (DM basis).

\begin{tabular}{lccc}
\hline & \multicolumn{3}{c}{ Diets } \\
\cline { 2 - 4 } & Flaxseed & Megalac & $\begin{array}{c}\text { Micronized } \\
\text { soybeans }\end{array}$ \\
\hline CP, \% of DM & 25.2 & 0 & 42.5 \\
Ether extract, \% of DM & 31.4 & 76.4 & 24.4 \\
ADF, \% of DM & 21.7 & 0 & 5.6 \\
NDF, \% of DM & 34.3 & 0 & $\mathrm{ND}^{1}$ \\
Fatty acids, \% of total fatty acids & & \\
C10:0 & 0 & 0.6 & 0 \\
C12:0 & 0 & 1.6 & 0 \\
C14:0 & 0 & 6.2 & 0 \\
C14:1 & 0 & 0.3 & 0 \\
C16:0 & 5.2 & 47.1 & 11.9 \\
C16:1 & 0 & 0.3 & 0 \\
C18:0 & 3.4 & 3.5 & 3.3 \\
C18:1 & 18.5 & 32.3 & 20.8 \\
C18:2 & 16.1 & 7.8 & 56.9 \\
C18:3 & 56.8 & 0.3 & 7.1 \\
\hline
\end{tabular}

${ }^{1} \mathrm{ND}=$ Not determined.

immune response of the dairy cow. The objective of this experiment was to determine the effect of FLA diet, rich in omega-3 FA, compared with other dietary FA on the functional properties of immunocompetent cells of the dairy cow within the first $21 \mathrm{~d}$ after calving and around the breeding period.

\section{MATERIALS AND METHODS}

\section{Diets and Animals}

The experiment was conducted at the Dairy and Swine Research and Development Centre, Lennoxville, QC, from November 1998 to May 1999 using 30 lactating Holstein cows (22 multiparous and 8 primiparous) in a complete block design. Cows of same parity within blocks were assigned randomly to one of three dietary treatments. The three total mixed diets (Table 1) consisted of fat supplements (Table 2) based on either FLA, calcium salts of palm oil, Megalac, or micronized soybeans (SOY). Cows were housed in tie stalls, fed individually, and milked twice daily at 0545 and $1645 \mathrm{~h}$. Water was available ad libitum. The experiment was carried out from calving until 105 DIM. All cows were treated and fed similarly before calving. Cows were introduced gradually to treatments over a 7-d period starting at calving. The three treatments were designed to yield similar $\mathrm{CP}$, ether extract, and $\mathrm{NE}_{\mathrm{L}}$ concentrations and were formulated to meet requirements for cows that were a mean $580 \mathrm{~kg}$ of BW and produced 40 $\mathrm{kg} / \mathrm{d}$ of milk with $3.5 \%$ fat (NRC, 1989). Feed consumption was recorded daily. Diets were fed twice daily for $10 \%$ orts. Total mixed diets were sampled weekly, frozen, and composited on a 4-wk basis. Composited samples were mixed thoroughly and subsampled for chemi- 
cal analyses according to the methods already used by Petit (2002) in a companion experiment.

Cows were observed for signs of estrus for a 30-min period four times daily $(0600,1300,1630$, and 2030 h) and were inseminated with frozen-thawed semen within $12 \mathrm{~h}$ of detected estrus by one of two technicians after a minimum of $60 \mathrm{~d}$ on the diets. Semen came from a single ejaculate of two bulls ensuring that equal numbers of cows from each treatment group were bred to each bull. All cows were inseminated between d 60 and 72 postpartum. At AI all cows were injected subcutaneously with $2 \mathrm{mg}$ of ovalbumin (OVA) grade V (Sigma, Oakville, ON, Canada) in incomplete Freund's adjuvant (Gibco BRL, Toronto, ON, Canada). A second injection was given on d 20 after AI.

\section{Blood Sampling for Peripheral Blood Mononuclear Cells Isolation}

Blood samples were taken on d 5, 21, 42, and 105 after calving and on $\mathrm{d} 0,10,20$, and 40 post AI. Blood from the caudal vein was drawn into $\mathrm{K}_{3}$ EDTA-vacuum tube (Becton Dickinson and Cie, Rutherford, NJ) for peripheral blood mononuclear cells (PBMC) isolation. At the same time, one blood sample was taken into a vacuum tube with no additive for preparation of heatinactivated $\left(56^{\circ} \mathrm{C}, 30 \mathrm{~min}\right)$ autologous serum $(\mathbf{A S})$.

The PBMC were isolated from whole blood by density gradient separation. Briefly, blood samples were layered on Ficoll-Hypaque Plus (Amersham Pharmacia, Montreal, QC, Canada), and PBMC were collected at the interface after centrifugation $(400 \times g$ for $40 \mathrm{~min})$ and washed twice with Hank's balanced salt solution (HBSS) without $\mathrm{Ca}^{2+}$ and $\mathrm{Mg}^{2+}$ (Gibco BRL). Finally, PBMC were resuspended in RPMI-1640 medium (Gibco BRL) supplemented with $12 \mathrm{~m} M$ HEPES, $2 \mathrm{~m} M$ glutamine, $23 \mathrm{~m} M$ sodium bicarbonate, $28 \mu M$ 2-mercaptoethanol, and $1 \%$ antibiotic-antimycotic solution (Gibco BRL). The number of viable cells was determined by trypan blue exclusion using a haemocytometer and was always greater than $95 \%$.

\section{Proliferation of Peripheral Blood Mononuclear Cells}

The PBMC were diluted at $2.5 \times 10^{6} \mathrm{cells} / \mathrm{ml}$ and plated in triplicate into 96 -well flat-bottom microtiter plates (Becton Dickinson) at a volume of $50 \mu \mathrm{l}$ with 100 $\mu \mathrm{l}$ of RPMI 1640 supplemented with $5 \%$ AS or $5 \%$ fetal bovine serum (FBS; Gibco BRL). Concanavalin A (ConA), a polyclonal T-lymphocyte mitogen, was added to obtain a final concentration of $0,0.125,0.5$, and 1 $\mu \mathrm{g} / \mathrm{ml}$ in the medium supplemented with AS and of 0 , $0.06,0.125$, and $0.5 \mu \mathrm{g} / \mathrm{ml}$ in medium supplemented with FBS. Plates were incubated at $37^{\circ} \mathrm{C}$ in $5 \% \mathrm{CO}_{2}$ air for $72 \mathrm{~h}$. A 5-bromo-2-deoxyuridine (BrdU) solution was added to the cells (50 $\mu \mathrm{l} /$ well of $1: 250$ in RPMI 1640), which were then reincubated for another $16 \mathrm{~h}$. The quantification of cell proliferation was based on the measurement of BrdU incorporation during DNA synthesis (BrdU kit: Roche Diagnostic, Laval, QC, Canada). Anti-BrdU conjugate with peroxydase was used for the colorimetric detection of cell proliferation. Absorbance value read on a Spectra Max 250 ELISA reader (Molecular Devices, Sunnyvale, CA) at $370 \mathrm{~nm}$ (reference wavelength: $492 \mathrm{~nm}$ ) directly correlated with the proliferation response of PBMC. The developed color and thereby the absorbance values directly correlate to the amount of DNA synthesis. The values were expressed as optical density units.

\section{Production of Bovine Interferon- $\gamma$}

For analysis of bovine interferon- $\gamma($ IFN- $\gamma)$ in supernatants, PBMC were adjusted at $1 \times 10^{7}$ cells $/ \mathrm{ml}$ and were cultured in RPMI 1640 supplemented with ConA $(5 \mu \mathrm{g} / \mathrm{ml})$ and $5 \%$ AS in 24-well microplates for $24 \mathrm{~h}$ at $37^{\circ} \mathrm{C}$ in a $5 \% \mathrm{CO}_{2}$ air. Culture supernatants were collected after centrifugation and stored at $-80^{\circ} \mathrm{C}$ until assayed. Bovine IFN- $\gamma$ was measured using an ELISA kit (Bovigam; CSL Veterinary, Parkville, Australia), and samples were measured in duplicate within the linear portion of the standard curve of recombinant bovine IFN- $\gamma$ (Novartis, Basel, Switzerland). Intra- and interassay coefficients of variation were 5 and $10 \%$, respectively.

\section{Production of Prostaglandin $\mathrm{E}_{\mathbf{2}}$}

PBMC suspension adjusted at $1 \times 10^{7}$ cell $\mathrm{s} / \mathrm{ml}$ in RPMI supplemented with 5\% AS was placed in a $24-$ well microplate and incubated for $18 \mathrm{~h}$ at $37^{\circ} \mathrm{C}$ in $5 \%$ $\mathrm{CO}_{2}$ air. After incubation, the plates were centrifuged, and the cells were resuspended in HBSS without $\mathrm{Ca}^{2+}$ and $\mathrm{Mg}^{2+}$, washed two more times, and finally resuspended in fresh RPMI-1640 supplemented with 5\% AS and $0.5 \mu \mathrm{g} / \mathrm{ml}$ lipopolysaccharide (LPS; Escherichia coli 055:B5, Sigma). The cells were then incubated for $6 \mathrm{~h}$. Culture supernatants were collected after centrifugation and stored at $-80^{\circ} \mathrm{C}$ until assayed. Prostaglandin $\mathrm{E}_{2}$ was extracted with absolute ethyl alcohol (10:1; Sigma) as proposed by Laforest and King (1992). Briefly, $300 \mu \mathrm{l}$ of supernatant and $100 \mu \mathrm{l}$ of standard (10 to $0.15 \mathrm{ng} / \mathrm{ml}$ ) were extracted and then resuspended in $100 \mu \mathrm{l}$ of radioimmunoassay buffer. The $\mathrm{PGE}_{2}$ was measured by radioimmunoassay test as described by Jaffe and Behrman (1974) using anti-PGE ${ }_{2}$ antibody (ICN Biomedicals Inc., Aurora, OH). Intra- and interassay coefficients of variation were 8 and $12 \%$, respectively. 


\section{Ovalbumin Antibody Detection}

Serum taken on d 0, 10, 20, 30, and 40 after AI was separated from coagulated blood by centrifugation and stored frozen $\left(-20^{\circ} \mathrm{C}\right)$ until time of assay. Antibody against OVA was measured by ELISA and quantified based on optical density measurements according to the procedure described by Mallard et al. (1997) with some modifications. Briefly, dilutions of cow serum (1/ 50 and 1/200) were added in duplicate to 96-well flatbottom microtiter MaxiSorp-plates (Canadian Life, Toronto, ON, Canada) coated with $2.5 \mu \mathrm{g} / \mathrm{ml}$ OVA grade $\mathrm{V}$ (Sigma). After washing to remove excess unbound antibodies, anti-OVA antibodies were detected with rabbit anti-bovine IgG (whole molecule)-alkaline phosphatase conjugate (1/50,000 working dilution; Sigma). P-Nitrophenyl phosphate alkaline phosphatase substrate (Sigma) was used for color development. Plates were read on a Spectra Max 250 ELISA reader (Molecular Devices) at $405 \mathrm{~nm}$ (reference wavelength: $630 \mathrm{~nm}$ ) until an optical density close to 1.7 was reached by the $1 / 200$ dilution of positive control serum reached. The diluted positive control serum was used to standardize the interassay. Intra- and interassay coefficients of variation were 5 and $12 \%$, respectively.

\section{Determination of Progesterone, Prostaglandin $\mathrm{E}_{2}$, and Fatty Acids in Serum}

Serum on d 5 and 21 after calving and on d 0 and 20 after AI was separated from coagulated blood by centrifugation and stored frozen $\left(-20^{\circ} \mathrm{C}\right)$ until time of assay. Serum concentration of progesterone $\left(\mathbf{P}_{4}\right)$ was measured using a radioimmunoassay test as described by Guilbault et al. (1988) and intra- and interassay coefficients of variation were 8 and 10\%, respectively. Serum concentration of $\mathrm{PGE}_{2}$ was measured using the radioimmunoassay test described above. Briefly, $25 \mu \mathrm{l}$ of serum and standard (40 to $0.6 \mathrm{ng} / \mathrm{ml}$ ) were extracted and resuspended in $100 \mu \mathrm{l}$ of radioimmunoassay buffer and then, $\mathrm{PGE}_{2}$ was measured by radioimmunoassay. Serum concentrations of FA were measured after their extraction using the procedures outlined by Delbecchi et al. (2001), and the preparation of serum FA methyl esters as described by Folch et al. (1957). Methyl ester profiles of FA were measured by GLC on a HewlettPackard 6890 chromatograph (Hewlett-Packard Ltd, Montreal, QC, Canada) with a G1315A autosampler equipped with a flame-ionization detector and a splitsplitless injector as described by Delbecchi et al. (2001).

\section{Statistical Analysis}

Data were analyzed as repeated measurement using PROC MIXED of SAS (SAS Institute, 2000). The model included diet, time (postcalving or post-AI), and the interaction (diet $\times$ time). Cows were bred on different dates and measurements were taken according to $\mathrm{AI}$; thus, block was not a source of variation in the model. Treatment sums of squares were partitioned using nonorthogonal contrasts and compared to evaluate 1) Megalac vs. FLA, 2) FLA vs. SOY. Probability values greater than 0.10 were considered nonsignificant. Data were assessed for normality, and a logarithmic transformation was used before the analysis of in vitro productions of IFN- $\gamma$ and $\mathrm{PGE}_{2}$ and blood concentration of $\mathrm{P}_{4}$. Finally, five cows per treatment were randomly selected to evaluate effect of dietary treatments on concentration of FA, $\mathrm{PGE}_{2}$ in blood after calving and at AI. Evaluation of treatment effects on blood concentration of $\mathrm{P}_{4}$ after calving was determined on the same five cows, and only cows that became pregnant after $\mathrm{AI}(\mathrm{n}=4,3$, 2 for Megalac, FLA, and SOY, respectively) were kept for statistical analysis to ensure similar physiological status of cows.

\section{RESULTS}

\section{Serum Fatty Acid Composition}

Dietary effects on serum FA on d 5 and 21 after calving are presented in Table 3. Concentration of C16:1 was greater $(P=0.06)$ for cows fed FLA compared with those fed Megalac. Concentrations of C14:0, C18:1t9, and $\mathrm{C} 18: 2 \mathrm{c} 6$ were lower $(P=0.07, P=0.08$, and $P=0.01$, respectively) for cows fed FLA compared with those fed SOY, while the inverse was observed for concentrations of C16:1, C18:1c9, and $\gamma \mathrm{C} 18: 3 \mathrm{n} 6(P=0.01, P=0.02$, and $P=0.01$, respectively). There was only one significant interaction between diet and day; concentration of C18:3n3 increased from d 5 to d 21 in cows fed FLA, while it remained similar for those fed Megalac and SOY. The lowest omega 6 to omega 3 FA ratio was observed for cows fed FLA compared with those fed either Megalac $(P=0.05)$ or SOY $(P<0.001)$. Concentrations of C16:0, C16:1, C18:0, C18:1t9, and C18:1c9 decreased $(P<0.05)$, while the inverse was observed $(P<$ 0.05 ) for concentrations of $\mathrm{C} 18: 2 \mathrm{c} 6, \gamma \mathrm{C} 18: 3 \mathrm{n} 6, \mathrm{C} 20: 3 \mathrm{n} 6$, $\mathrm{C} 20: 4 \mathrm{n} 6$, and $\mathrm{C} 20: 5 \mathrm{n} 3$ from d 5 to d 21 after calving.

Concentrations of individual FA in serum changed between day of AI and d 20 after AI (Table 4). There was an interaction $(P=0.02)$ between diet and day for concentration of C14:0; it decreased from day of AI to $20 \mathrm{~d}$ after AI for cows fed SOY, while there was a slight increase for cows fed Megalac and FLA. Concentrations of C16:0 and C20:4n6 were greater $(P<0.0001$ and $P$ $=0.04$, respectively) for cows fed Megalac than for those fed FLA, while the inverse was observed for concentrations of $\mathrm{C} 18: 0$ and $\mathrm{C} 20: 5 \mathrm{n} 3(P=0.004$ and $P=0.09$, respectively). Cows fed FLA had greater concentrations 
Table 3. Fatty acid composition ( $\%$ of total FA) of bovine serum on d 5 and 21 after calving. ${ }^{1,2}$

\begin{tabular}{|c|c|c|c|c|c|c|c|c|c|c|c|c|}
\hline \multirow[b]{3}{*}{ Fatty acids } & \multirow{2}{*}{\multicolumn{4}{|c|}{ d 5}} & \multirow{2}{*}{\multicolumn{4}{|c|}{ d 21}} & \multicolumn{4}{|c|}{$P$ value } \\
\hline & & & & & & & & & \multirow{2}{*}{$\begin{array}{l}\text { MEG vs. } \\
\text { FLA }\end{array}$} & \multirow{2}{*}{$\begin{array}{l}\text { FLA vs. } \\
\text { SOY }\end{array}$} & \multirow[b]{2}{*}{ Day } & \multirow[b]{2}{*}{ Diet $\times$ day } \\
\hline & FLA & MEG & SOY & SEM & FLA & MEG & SOY & SEM & & & & \\
\hline C16:0 & 19.13 & 19.23 & 19.41 & 0.97 & 13.18 & 15.98 & 14.21 & 0.88 & 0.32 & 0.78 & 0.005 & 0.35 \\
\hline C16:1 & 2.85 & 2.20 & 1.91 & 0.20 & 1.81 & 1.44 & 1.30 & 0.19 & 0.06 & 0.01 & 0.01 & 0.52 \\
\hline C18:0 & 16.80 & 16.36 & 17.31 & 0.80 & 15.76 & 13.80 & 14.19 & 0.72 & 0.26 & 0.74 & 0.03 & 0.44 \\
\hline C18:1t9 & 0.74 & 0.86 & 1.29 & 0.13 & 0.62 & 0.70 & 0.79 & 0.12 & 0.81 & 0.08 & 0.04 & 0.21 \\
\hline$\gamma \mathrm{C} 18: 3 \mathrm{n} 6$ & 0.19 & 0.09 & 0.00 & 0.11 & 0.70 & 0.72 & 0.22 & 0.10 & 0.92 & 0.01 & 0.01 & 0.26 \\
\hline C18:3n3 & 5.09 & 4.95 & 3.00 & 0.49 & 9.11 & 3.78 & 3.62 & 0.44 & 0.001 & 0.001 & 0.05 & 0.02 \\
\hline C20:3n6 & 0.41 & 0.48 & 0.34 & 0.26 & 1.36 & 1.70 & 1.08 & 0.24 & 0.75 & 0.81 & 0.01 & 0.44 \\
\hline $\mathrm{C} 20: 4 \mathrm{n} 6$ & 0.97 & 1.31 & 1.64 & 0.24 & 1.75 & 1.97 & 1.82 & 0.22 & 0.56 & 0.37 & 0.03 & 0.30 \\
\hline C20:5n3 & 0.16 & 0.52 & 0.18 & 0.20 & 1.16 & 0.98 & 0.50 & 0.18 & 0.87 & 0.20 & 0.03 & 0.28 \\
\hline Omega- & & & & & & & & & & & & \\
\hline 6/omega-3 & 6.30 & 6.68 & 14.07 & 1.30 & 4.68 & 10.43 & 13.55 & 1.16 & 0.05 & 0.001 & 0.62 & 0.21 \\
\hline
\end{tabular}

${ }^{1}$ Fat supplement based on FLA = whole flaxseed, MEG = Megalac, and SOY = micronized soybeans.

${ }^{2}$ Least squares means $(n=5)$.

of C16:1 $(P=0.01)$ and $\mathrm{C} 20: 5 \mathrm{n} 3(P<0.001)$, and they had lower $(P<0.001)$ concentrations of $\mathrm{C} 18: 2 \mathrm{c} 6$ than those fed SOY. There was a more important decrease in C18:1c9 concentration over time for cows fed FLA compared with those fed Megalac and SOY, which led to a significant interaction between diet and day. There was an interaction $(P=0.04)$ between diet and day for concentration of $\gamma \mathrm{C} 18: 3 \mathrm{n} 6$; it increased for cows fed Megalac, while it remained similar for cows fed FLA and SOY. A diet $\times$ day interaction was also significant for concentration of $\mathrm{C} 18: 3 \mathrm{n} 3$ as $\mathrm{C} 18: 3 \mathrm{n} 3$ increased in cows fed FLA, while it remained similar in cows fed SOY and Megalac. There was an interaction $(P=0.05)$ between diet and day for concentration of C20:3n6; concentration remained similar over time for cows fed Meg- alac, and it increased for those fed SOY and FLA. Cows fed FLA had a lower $(P<0.001)$ omega- 6 to omega-3 FA ratio than those fed Megalac and SOY. Concentrations of $\mathrm{C} 16: 0$ and $\mathrm{C} 16: 1$ decreased $(P=0.03$ and $P=$ $0.04)$ from day of AI to d 20 after AI.

\section{Blood Concentrations of Progesterone and Prostaglandin $\mathrm{E}_{2}$}

There was no interaction diet $\times$ day for $\mathrm{P}_{4}$ concentration. Concentration of $\mathrm{P}_{4}$ increased significantly from d 5 to 21 after calving for all treatments (Figure 1A). Diet had no effect after calving on serum $\mathrm{P}_{4}$ concentration during the early postcalving period. Serum concentrations of $\mathrm{P}_{4}$ were lower $(P<0.001)$ at $\mathrm{AI}$ than on $\mathrm{d}$

Table 4. Fatty acid composition (\% of total FA) of bovine serum on d 0 and 20 after the first AI. ${ }^{1,2}$

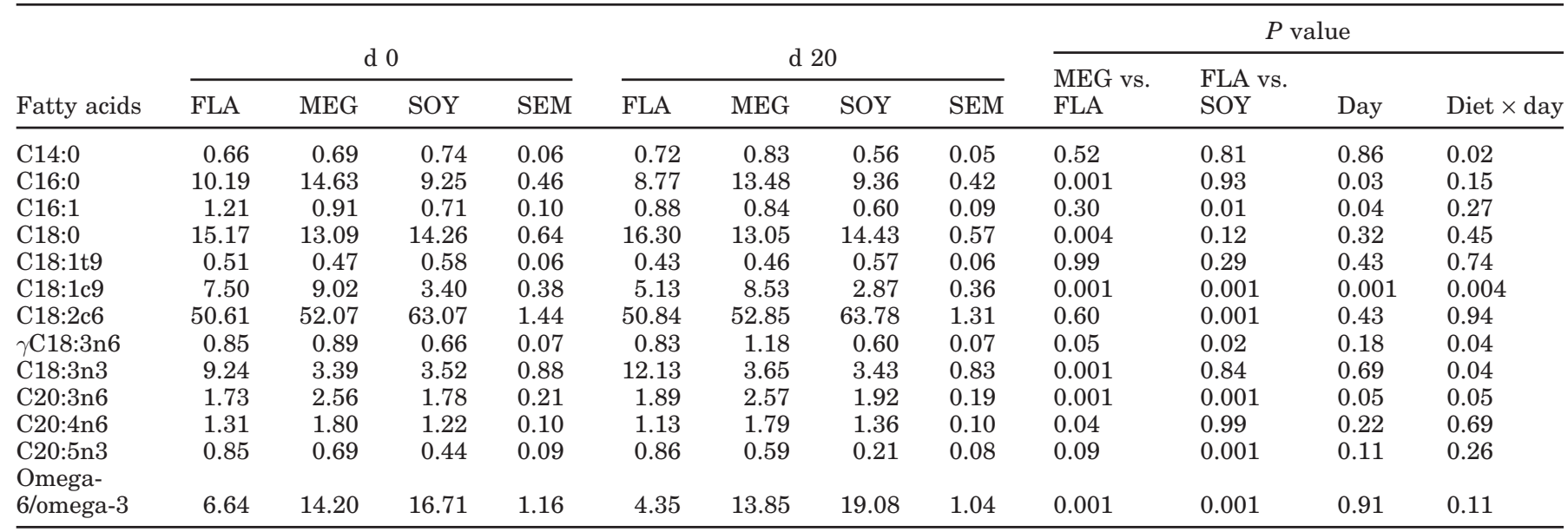

${ }^{1}$ Fat supplement based on FLA = whole flaxseed, MEG = Megalac, and SOY = micronized soybeans.

${ }^{2}$ Least squares means $(n=5)$. 

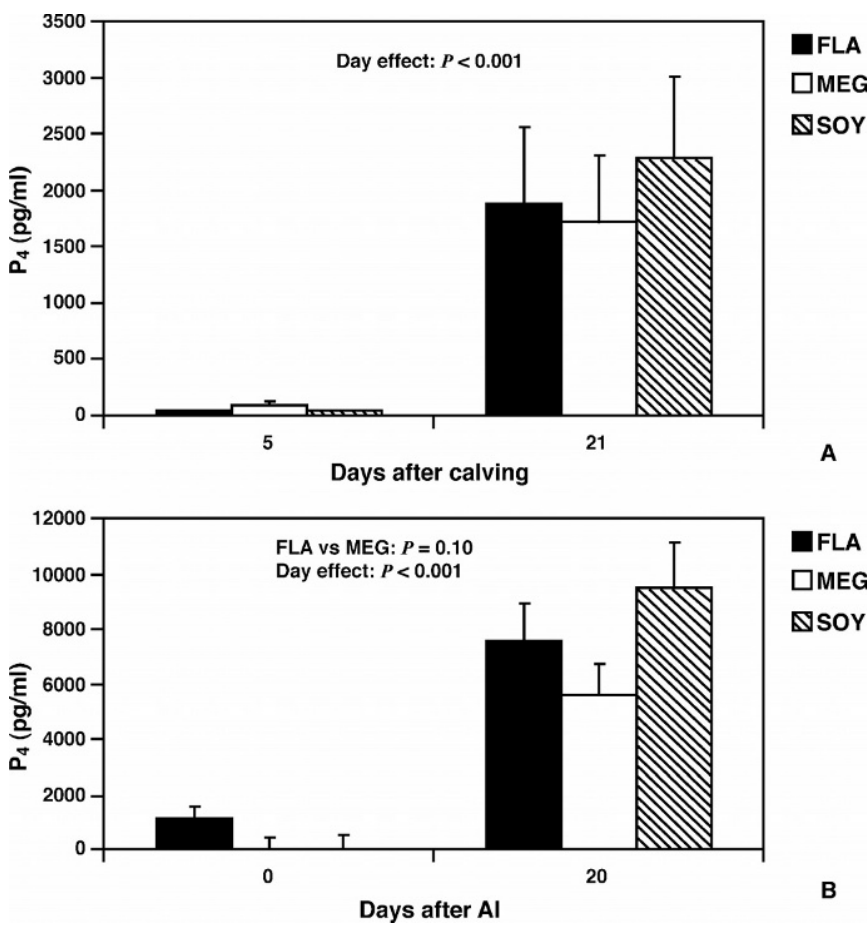

Figure 1.Serum concentration of progesterone $\left(\mathrm{P}_{4}\right)$ after calving (A) and after the first detected estrus (B) for artificial insemination (AI) in dairy cows fed flaxseed (FLA), micronized soybeans (SOY) or Megalac (MEG). Each bar represents the means \pm SEM. After calving $(\mathrm{n}=5)$ and after AI, analysis was performed only on gestating cows (n = 4, 3, 2 for MEG, FLA, and SOY, respectively).

20 post AI (Figure 1B). During the breeding period, based on data obtained from cows that became pregnant after AI, a significant dietary effect showed that mean concentrations of $\mathrm{P}_{4}$ from d 0 to 20 were greater for cows fed FLA than for those fed Megalac.

Serum $\mathrm{PGE}_{2}$ concentration was similar among diets and between days of sampling during the early postcalving period (Figure 2A). After AI (Figure 2B) there was no interaction $(P>0.10)$ between day and diet for $\mathrm{PGE}_{2}$ concentration, and concentrations were similar for both sampling days. However, cows fed FLA had lower $(P=0.04) \mathrm{PGE}_{2}$ concentration than those fed Megalac or SOY during the breeding period.

\section{Lymphocyte Response to Concanavalin A After Calving and Around Al}

After calving, there was a significant interaction between day and diet for the lymphocyte proliferative response to ConA when cells were incubated with FBS (Figure 3A), indicating that the profile of lymphocyte response to suboptimal concentration of ConA was different for cows fed FLA compared with those fed Megalac and SOY. This interaction was due to a reduced
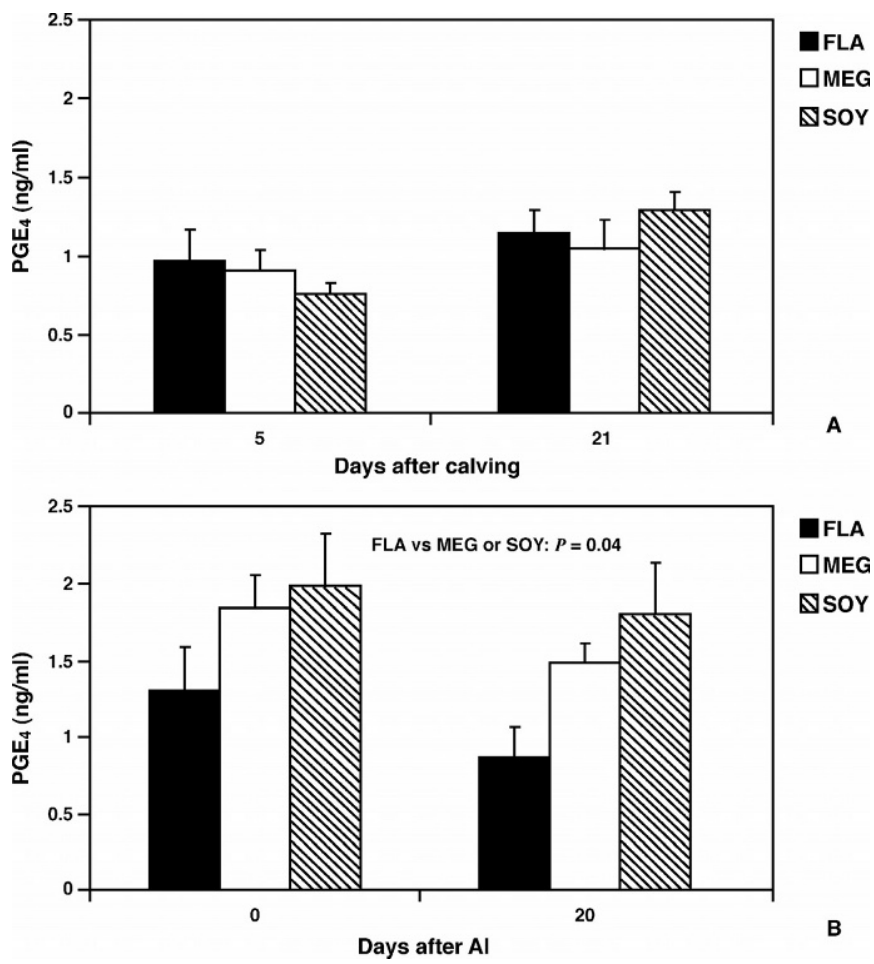

Figure 2. Serum concentration of prostaglandin $\left(\mathrm{PGE}_{2}\right)$ after calving $(\mathbf{A})$ and after the first detected estrus (B) for AI in dairy cows fed flaxseed (FLA), micronized soybeans (SOY), or Megalac (MEG). Each bar represents the means $\pm \operatorname{SEM}(n=5)$.

proliferative response of activated PBMC on d 5 after calving in cows fed FLA compared with cows fed the other diets. No significant difference was found with other concentrations of ConA when cells were incubated with FBS (data not shown). There was no diet $\times$ day interaction when AS was added to cultures (Figure 3B). Diet and day of sampling had no effect in AS cultures.

During the breeding period, the interaction between day and diet for the proliferative response of ConAactivated PBMC was significant when the cells were incubated with AS (Figure 4B), indicating that PBMC proliferation response of cows fed FLA showed a different time effect compared with cows fed Megalac and SOY. On d 20 after AI, cows fed FLA had a lower lymphocyte proliferation than cows fed the other diets. No significant difference was found with other concentrations of ConA when cells were incubated with AS (data not shown). When the cells were cultured in presence of FBS (Figure 4A), lymphocyte responses to ConA were not affected by dietary treatments, and there was no significant diet $\times$ day interaction.

\section{In Vitro Production of Interferon- $\gamma$ and Prostaglandin $\mathrm{E}_{2}$ After Calving, and Around Al}

In vitro productions of IFN- $\gamma$ (Figure $5 \mathrm{~A})$ and $\mathrm{PGE}_{2}$ (Figure 5B) were determined at different times after 

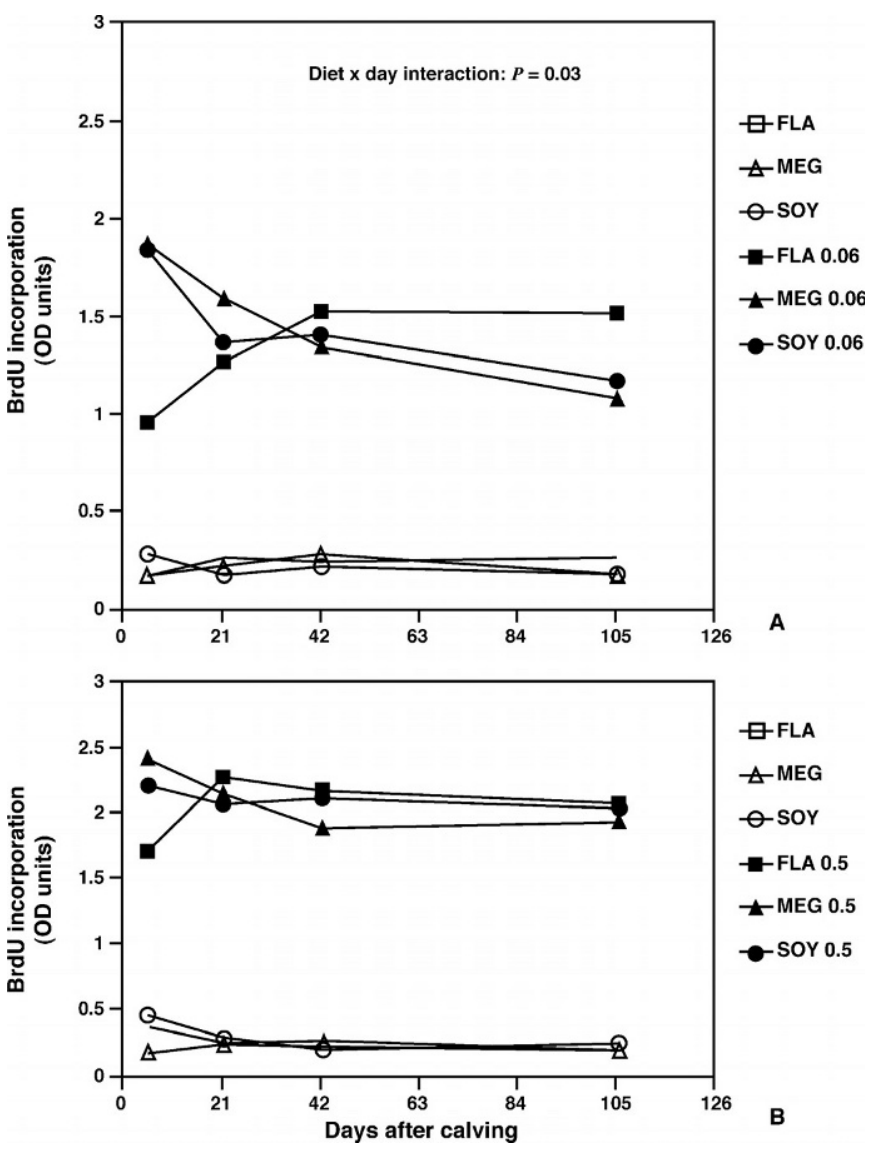

Figure 3. Effect of dietary fatty acids on proliferative response of peripheral blood mononuclear cells to concanavalin A (ConA) after calving in dairy cows fed flaxseed (FLA), micronized soybeans (SOY), or Megalac (MEG). Cells were incubated either with (A) fetal bovine serum (FBS) or (B) serum autologous (AS) and, respectively, stimulated with 0.06 and $0.5 \mu \mathrm{g} / \mathrm{ml}$ of ConA. Open symbols show results for non-stimulated cells $(\mathrm{n}=10 ; \mathrm{SEM}=0.075$ and 0.124 for FBS and AS cultures, respectively) and black symbols for stimulated cells (n $=10 ; \mathrm{SEM}=0.294$ and 0.260 for FBS and AS cultures, respectively). Incorporation of BrdU was determined by ELISA and quantified based on optical density measurement.

calving. Dietary treatment had no effect on IFN- $\gamma$ and $\mathrm{PGE}_{2}$ productions of ConA and LPS-activated PBMC, and there was no interaction between diet and day after calving. However, on average in vitro productions of IFN- $\gamma$ and $\mathrm{PGE}_{2}$ by PBMC were significantly affected by time. Data showed that productions of IFN- $\gamma$ and $\mathrm{PGE}_{2}$ by activated PBMC were impaired in the first 3 wk postcalving compared with d 42 .

In vitro production of IFN- $\gamma$ after AI (Figure 6) was not affected by dietary treatments, and there was no interaction between diet and day after AI. However, a time effect was significant. On average, in vitro production of IFN- $\gamma$ by activated PBMC was reduced $(P=0.01)$ after AI.
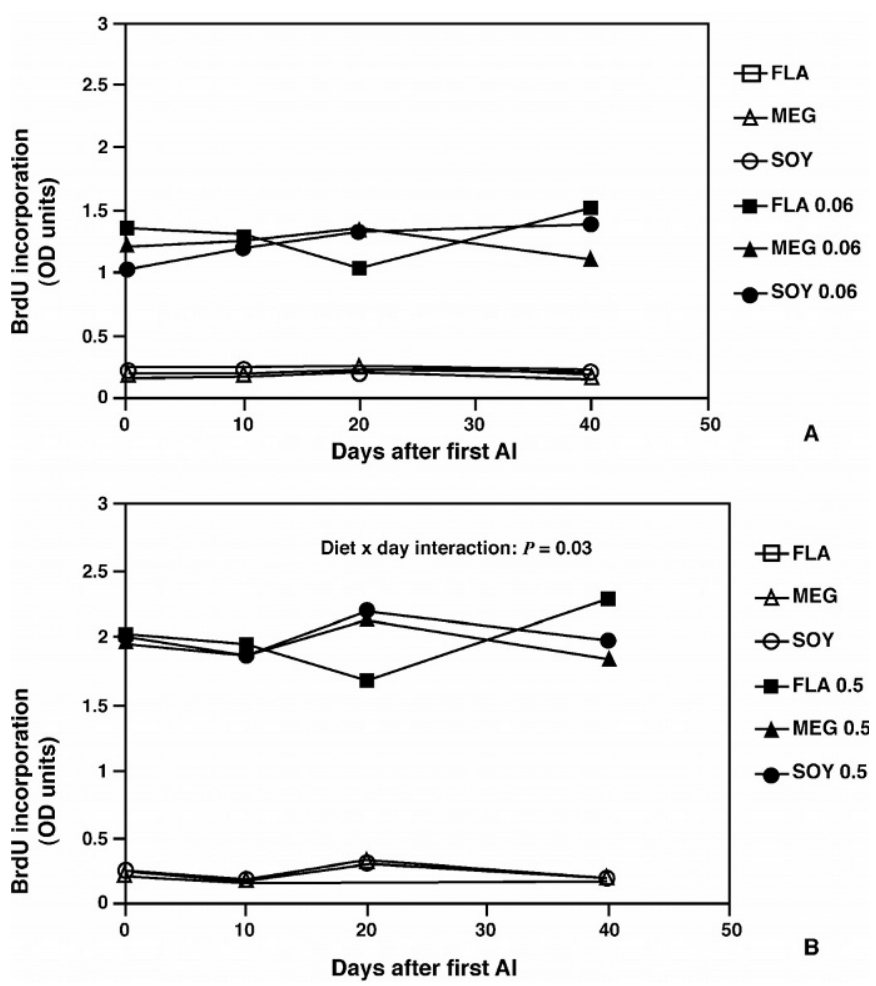

Figure 4. Effect of dietary fatty acids on proliferative response of peripheral blood mononuclear cells to concanavalin A (ConA) after the first AI in dairy cows fed flaxseed (FLA), micronized soybeans (SOY), or Megalac (MEG). Cells were incubated either with (A) fetal bovine serum (FBS) or (B) serum autologous (AS) and, respectively, stimulated with 0.5 and $0.06 \mu \mathrm{g} / \mathrm{ml}$ of ConA. Open symbols show results for nonstimulated cells $(n=10$; $\mathrm{SEM}=0.064$ and 0.073 for FBS and AS cultures, respectively) and black symbols for stimulated cells $(n=10 ; \mathrm{SEM}=0.197$ and 0.207 for FBS and AS cultures, respectively). Incorporation of BrdU was determined by ELISA and quantified based on optical density measurement.

\section{Dietary Effect on Ovalbumin Antibody Production}

A day effect $(P<0.001)$ was observed during OVA immunization (primary and secondary responses). The antibody response to OVA production was similar among treatments, and there was no interaction between diet and day after AI (Figure 7).

\section{DISCUSSION}

The present study was designed to investigate the influence of diet enriched in omega-3 and omega- 6 FA on blood FA profile, cellular immunity, and antibody response in early postpartum dairy cows. Feeding cows with FLA, SOY, or Megalac rapidly affected composition of blood FA. In the first $21 \mathrm{~d}$ after calving, blood concentrations of omega-3 FA increased in cows fed FLA, which resulted in a marked reduction in the omega-6 to omega-3 FA ratio in cows fed FLA compared to those fed SOY or Megalac. At breeding time, differ- 

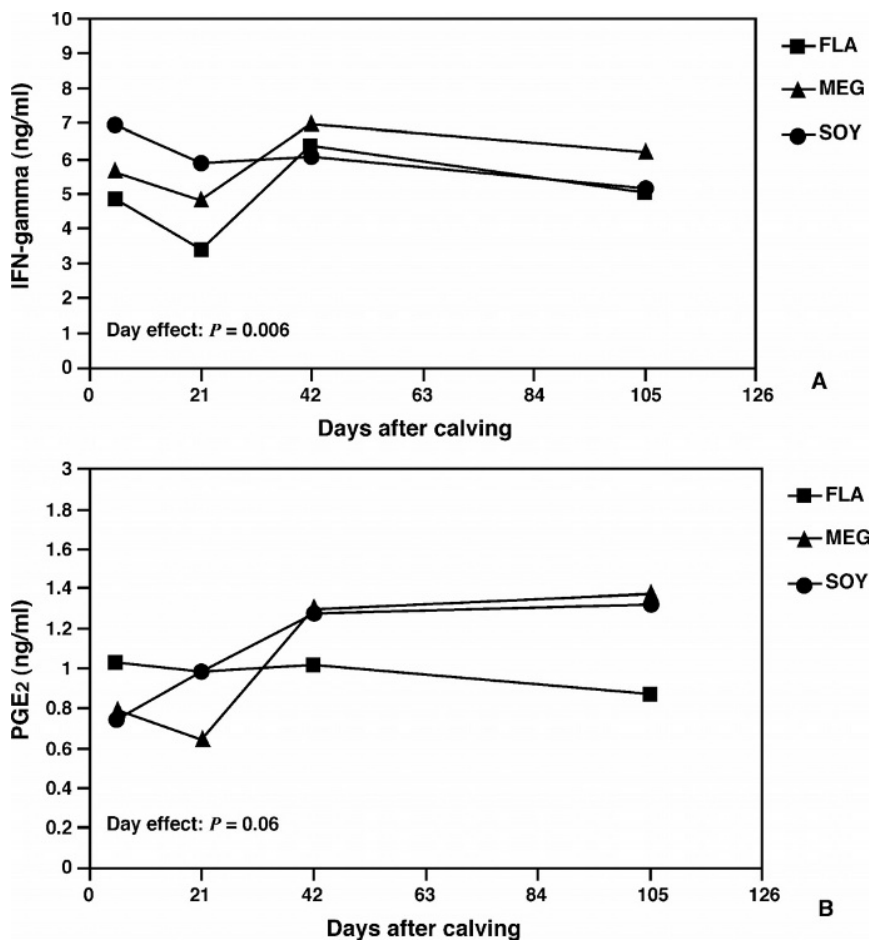

Figure 5. In vitro production of interferon- $\gamma($ IFN- $\gamma)(\mathbf{A})$ and prostaglandin $(\mathrm{PG}) \mathrm{E}_{2}(\mathbf{B})$ by activated peripheral blood mononuclear cells after calving in dairy cows fed flaxseed (FLA), micronized soybeans (SOY), or Megalac (MEG). (A) Cells were cultured in RPMI 1640 supplemented with concanavalin A $(5 \mu \mathrm{g} / \mathrm{ml})$ and $5 \%$ of autologous serum (AS) for $24 \mathrm{~h}$. (B) Cells were cultured in RPMI 1640 supplemented with lipopolysaccharide $(0.5 \mu \mathrm{g} / \mathrm{ml})$ and $5 \%$ AS for $6 \mathrm{~h}$. Standard error of means were 2.469 and 0.335 for $\mathrm{IFN}_{-} \gamma$ and $\mathrm{PGE}_{2}$, respectively $(\mathrm{n}=10)$.

ences in FA profile and in the omega- 6 to omega- 3 FA ratio between cows fed FLA and those fed SOY and Megalac were enhanced, indicating that dietary effect increased with time of treatment. These results support those obtained by Petit (2002) who reported that $10 \mathrm{wk}$ after calving, dairy cows fed FLA have an omega- 6 to omega-3 ratio three times lower than cows fed Megalac or SOY.

Lymphocytes and monocytes/macrophages play a major role in the establishment of immune responses. Studies carried out with laboratory animals or in vitro have shown that FA play important functions in the regulation of immune responses (Miles and Calder, 1998; Yaqoob and Calder, 1995). Similarly, in the present study, results suggest that cellular immunity of the dairy cow was affected by dietary FA. Five days after calving, the lymphocyte proliferative response of cows allocated to FLA was reduced compared with that of those receiving Megalac or SOY, as shown by the lower response of activated PBMC. This difference among dietary treatments on lymphocyte proliferative response within the first $21 \mathrm{~d}$ postpartum was unexpected be-

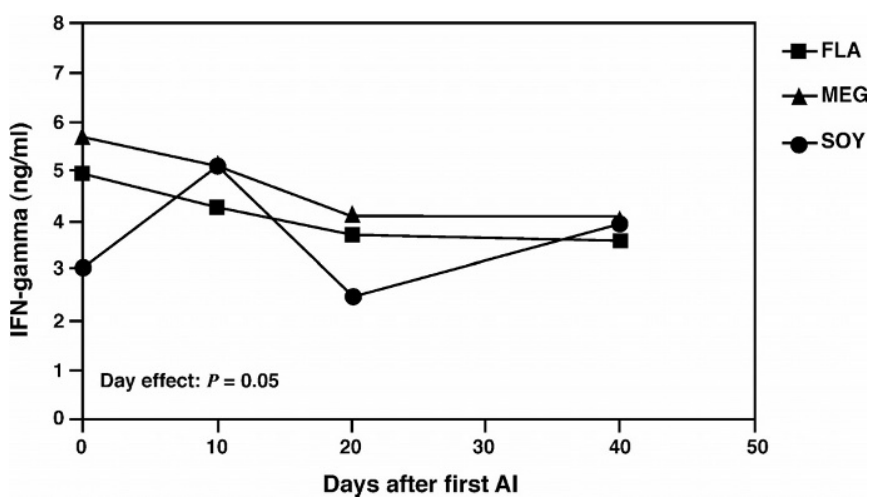

Figure 6. In vitro production of interferon- $\gamma($ IFN- $\gamma)$ by activated peripheral blood mononuclear cells after the first AI in dairy cows fed flaxseed (FLA), micronized soybeans (SOY), or Megalac (MEG). Cells were cultured in RPMI 1640 supplemented with concanavalin A $(5 \mu \mathrm{g} / \mathrm{ml})$ and $5 \%$ of autologous serum for $24 \mathrm{~h}$. Standard error of means was equal to $1.3(\mathrm{n}=10)$.

cause cows were still in the transition period, and they were not fully fed the experimental diets before the end of wk 1 postpartum. However, despite the short time of feeding with increased amounts of dietary FA post calving, the FA profile of cows was already affected as shown by the greater omega- 6 to omega-3 FA ratio on d 5 postpartum in cows allocated to SOY. The present study suggests that suppression of lymphocyte response to mitogenic stimulation that occurred during the periparturient period lasted longer in cows fed FLA than in those fed the other diets. In dairy cows, impaired lymphocyte proliferative response to mitogens occurs within the first $24 \mathrm{~h}$ after calving (Wells et al., 1977), and it can last for $1 \mathrm{wk}$ after calving as reported by Kehrli et al (1989). Severity and duration of the sup-

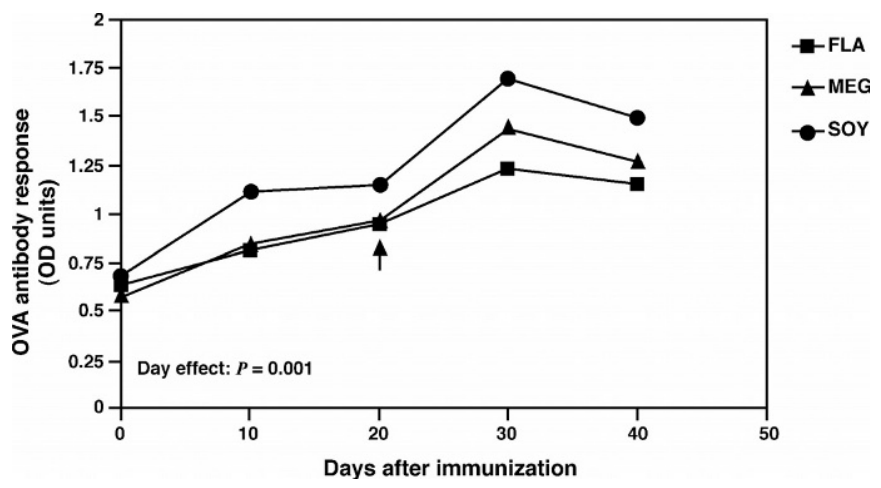

Figure 7. Antibody response against ovalbumin (OVA) in dairy cows fed flaxseed (FLA), micronized soybeans (SOY) or Megalac (MEG). Cows were injected with OVA on d 0 and 20 (arrow) after the first AI. Standard error of means was equal to $0.264(n=10)$. Antibody against OVA was measured by ELISA and quantified based on optical density measurement. 
pressive response to ConA have been less severe in primiparous than in multiparous cows (Kashiwazaki et al., 1985) and were correlated with the incidence of mastitis (Kashiwazaki, 1984). Therefore, dietary treatment modulating immune responses may also influence duration of immunosuppression postpartum. In the present study, lymphocyte proliferative responses of cows fed FLA increased after wk 1 postpartum to reach responses that were similar to those obtained in cows fed Megalac or SOY. This effect cannot be explained by blood concentrations of $\mathrm{P}_{4}$ and $\mathrm{PGE}_{2}$ on $\mathrm{d} 5$ postpartum and by the potential of activated leukocytes to produce $\mathrm{PGE}_{2}$ or IFN- $\gamma$, as they were similar among treatments and neither by blood FA composition since proliferative responses of PBMC in presence with autologous serum were not suppressed as much as those with FBS.

In mice, feeding diets enriched in omega-3 FA has inhibited in vitro production of $\mathrm{PGE}_{2}$ (Yaqoob and Calder, 1995) and modulated expression of IL-1, IL-6, and TNF- $\alpha$ at the protein and mRNA levels by macrophages (Miles and Calder, 1998). In the present study, in vitro productions of $\mathrm{PGE}_{2}$ and of IFN- $\gamma$ by activated PBMC were not affected by dietary treatments. Discrepancies between published results and those from the present experiment might result from differences between species and from the type of FA provided by the diet. For instance, fish oil provides eicosapentanoic and docosahexaenoic acids, while flaxseed contains alpha-linolenic acid. It is known that omega-3 FA from fish oil have more immunomodulatory activities than those provided by flaxseed (Calder et al., 2002). On the other hand, physiological changes that occur after calving can affect cellular immune responses and modulate the influence of dietary FA on immune functions. Indeed, both IFN$\gamma$ and $\mathrm{PGE}_{2}$ productions by activated PBMC were suppressed in the first $20 \mathrm{~d}$ after parturition regardless of dietary treatments. Previous studies also showed that IFN- $\gamma$ and IL-2 productions are suppressed during the periparturient period, suggesting suppression of cellular immune functions regulated by T lymphocytes (Ishikawa et al., 1994; Sordillo et al., 1995). The reduced production of $\mathrm{PGE}_{2}$ by LPS-activated PBMC during the first $21 \mathrm{~d}$ postpartum has not been reported anywhere before to our knowledge for dairy cows. Metabolic and hormonal changes occurring after calving and in early lactation could be responsible for the decreased production of $\mathrm{PGE}_{2}$ by LPS-activated PBMC.

After the first estrus detected $60 \mathrm{~d}$ postpartum and used as a basis for initiating breeding, the lymphocyte proliferative response to ConA was reduced in cows fed FLA compared with those fed SOY or Megalac on d 20 after AI compared with day of AI. The effect was greater when lymphocytes were incubated with AS than when they were incubated with FBS, suggesting that blood composition influences lymphocyte response. Although $\mathrm{PGE}_{2}$ concentration in blood was reduced in cows fed FLA compared with those fed Megalac or SOY, $\mathrm{PGE}_{2}$ may not be the only factor responsible for impaired lymphocyte transformation on d 20 after AI. Inhibition of T lymphocyte proliferation by omega-3 FA has been reported previously in rats fed diets containing large amounts of linseed oil compared with rats fed diets rich in hydrogenated coconut oil (Marshall and Johnston, 1985). Previous studies have demonstrated that $\gamma$-linolenic acid, an omega-6 FA, and eicosapentoneic acid, an omega-3 FA, inhibit mitogen-stimulated lymphocyte proliferation (Khalfoun et al., 1996; Purasiri et al., 1997), and the inhibition appears to be independent of the synthesis of eicosanoids such as PG and leukotrienes (Calder et al., 2002). Therefore, other mechanisms of action of PUFA must be considered. In fact, FA are known to affect gene expression, and one such mechanism could be through the regulation of cytokine gene expression by modulating the activation of transcription nuclear factors such as nuclear transcription factor kappa B and peroxisomal proliferator-activated receptors (Jump and Clarke, 1999).

In the present study, mean serum concentrations of $\mathrm{P}_{4}$ from d 0 to 20 after AI of cows fed FLA were higher than those of cows fed Megalac, which is in agreement with the greater $\mathrm{P}_{4}$ concentration reported by Petit et al. (2001) for cows fed flaxseed. Similarly, the proportion of cows with plasma $\mathrm{P}_{4}$ concentration greater than $1 \mathrm{ng} /$ $\mathrm{ml}$ at $\mathrm{AI}$ was larger when fish meal, which is high in omega-3 FA was included in the diet than when a control diet was fed (Burke et al., 1997). As suggested by Mattos et al. (2000) for fish meal, omega-3 FA contained in FLA could have reduced the sensitivity of the CL to $\mathrm{PGF}_{2 \alpha}$ or reduced the uterine secretion of $\mathrm{PGF}_{2 \alpha}$ that delayed the completion of functional luteolysis, resulting in incomplete CL regression. Suppression of $\mathrm{PGF}_{2 \alpha}$ secretion and maintenance of the CL are obligatory steps for establishment of pregnancy of cows (Thatcher et al., 1994). Successful embryo implantation (around d 16 post AI) and maintenance of pregnancy also require the maintenance of $\mathrm{P}_{4}$ secretion through the critical period of the maternal recognition of pregnancy (Hanzen et al., 1999; Lamming and Royal, 2001). Better conception rate for cows fed omega 3 FA could also result from decreased concentrations of $\mathrm{PGE}_{2}$ during the AI period as observed in the present experiment for cows fed FLA compared with those fed Megalac or SOY. Feeding omega-3 FA would then modulate secretions of $\mathrm{P}_{4}$ and $\mathrm{PGE}_{2}$, which would agree with the fact that cows fed FLA have greater blood $\mathrm{P}_{4}$ concentration and decreased embryo mortality compared with those fed Megalac or SOY as observed in a companion experiment (Petit and Twagiramungu, 2002) and that better 
reproduction could be achieved through a greater production of the less biologically active $\mathrm{PGE}_{1}$ at the expense of the normal $\mathrm{PGE}_{2}$ (Abayasekera and Wathes, 1999). The difference in the ability of different sources of FA to stimulate production of $\mathrm{PGE}_{2}$ may be attributable to the content of $\alpha$-linolenic acid, which can inhibit synthesis of the series 2 PG (Mattos et al., 2000). Dietary enrichment in omega-3 FA has decreased series 2 PG in blood of cattle (Staples et al., 2000; Petit et al., 2001).

During the breeding period, $\mathrm{P}_{4}$ and $\mathrm{PGE}_{2}$ concentrations were affected by composition of dietary unsaturated FA, and these effects could contribute to improvement of reproductive performance in cows because both molecules have important roles to regulate uterine and systemic immune responses and to create an optimal uterine environment to receive the conceptus in different species, including bovine (Emond et al., 1998; Hanzen et al., 1999). The results suggest that changes in $\mathrm{P}_{4}$ and $\mathrm{PGE}_{2}$ concentrations following estrus and $\mathrm{AI}$ influenced systemic immunity, as shown by the reduced proliferative response due to dietary treatment and by a decreased IFN- $\gamma$ production after AI. This transient suppression that was observed in the present study is similar to the results reported by Fusijaki et al. (1985), who observed that $\mathrm{P}_{4}$ and $\mathrm{PGE}_{2}$ at physiological concentration exhibit a synergistic immunosuppressive effect on proliferative response of human peripheral lymphocytes to mitogenic stimulation. However, mechanisms such as those mentioned above must be considered to explain the dietary effect on lymphocyte proliferative response to mitogenic stimulation since differences in $\mathrm{P}_{4}$ and $\mathrm{PGE}_{2}$ concentrations cannot be the only explanation. Other studies also demonstrated that maternal immune response during pregnancy shifts from cellular to humoral type immune responses, which is characterized by reduced production of IFN- $\gamma$ by immunocompetent cells (Martal et al., 1997; Raghupathy, 1997; Vacchio and Jiang, 1999). It has been also shown that $\mathrm{P}_{4}$ found at the maternal/fetal interface favored the generation of $\mathrm{T}$ helper cells producing Th2-type cytokines such as IL-4 (Piccinni et al., 1995). In the context of the present study, data interpretation has to be done with caution as conception rate, and the number of animals per treatment was low. Finally, in the present study, dietary composition of FA had no affect on the primary and secondary antibody responses to OVA of cows. Similar results were obtained in dogs (Wander et al., 1997) and rats (Matsuo et al., 1996).

\section{CONCLUSIONS}

In conclusion, feeding flaxseed decreased serum omega- 6 to omega-3 FA ratio in dairy cows. During the breeding period, blood concentration of prostaglandin $\mathrm{E}_{2}$ was reduced in cows fed flaxseed compared with those fed calcium salts of palm oil, Megalac, or micronized soybeans while $\mathrm{P}_{4}$ concentration was increased in cows fed flaxseed compared with those fed Megalac. After calving and breeding, lymphocyte proliferative responses of cows fed flaxseed were transiently reduced compared with those fed Megalac or micronized soybeans, suggesting that both dietary composition of FA and physiological status affect the functional properties of lymphocytes in dairy cows. Studies with a larger number of cows during the early phase of gestation need to be performed to confirm these results and to determine whether dietary FA through their influence on immune functions and production of prostaglandin $\mathrm{E}_{2}, \mathrm{P}_{4}$, and cytokines affect embryo survival, immunity, and reproductive performance of dairy cows. The influence of dietary FA on immune functions during the transition period needs also to be addressed.

\section{ACKNOWLEDGMENTS}

The authors would like to thank Liette Veilleux and Marie Dupuis for their excellent technical assistance, Steve Methot for statistical analyses, and the dairy barn staff for animal care and data collection. They also are grateful to Novartis (Basel, Switzerland) for generously supplying of the recombinant bovine IFN- $\gamma$.

\section{REFERENCES}

Abayasekara, D. R. E., and D. C. Wathes. 1999. Effects of altering dietary fatty acid composition on prostaglandin synthesis and fertility. Prostaglandins Leukot. Essent. Fatty Acids 61:275-287.

Burke, J. M., C. R. Staples, C. A. Risco, R. L. De La Sota, and W. W. Thatcher. 1997. Effect of ruminant grade menhaden fish meal on reproductive performance of lactating dairy cows. J. Dairy Sci. 80:3386-3398.

Calder, P. C., P. Yaqoob, F. Thies, F. A. Wallace, and E. A. Miles. 2002. Fatty acids and lymphocyte functions. Br. J. Nutr. 87:S31-S48.

Delbecchi, L., C. E. Ahnadi, J. J. Kennelly, and P. Lacasse. 2001. Milk fatty acid composition and mammary lipid metabolism in Holstein cows fed protected or unprotected canola seeds. J. Dairy Sci. 84:1375-1381.

Emond, V., M. A. Fortier, B. D. Murphy, and R. D. Lambert. 1998. Prostaglandin E2 regulates both interleukin-2 and granulocytemacrophage-colony stimulating factor gene expression in bovine lymphocytes. Biol. Reprod. 58:143-151.

Folch, J., M. Lees, and G. H. Sloane-Stanley. 1957. A simple method for the isolation and purification of total lipids from animal tissues. J. Biol. Chem. 226:497-509.

Fusijaki, S., K. Kawano, and Y. Haruama. 1985. Synergistic effect of progesterone on prostaglandin E modulation of the mitogenic response of human peripheral lymphocytes. J. Reprod. Immunol. $7: 15-26$.

Guilbault, L. A., G. L. Roy, F. Grasso, and P. Matton.1988. Influence of pregnancy on the onset of oestrus and luteal function after prostaglandin-induced luteolysis in cattle. J Reprod. Fertil. $84: 461-468$

Hanzen, C. H., O. Lourtie, P. V. Drion, C. Depierreux, and E. Christians. 1999. La mortalité embryonnaire. 2. Implications hormonales. Ann. Med. Vet. 143:179-189. 
Ishikawa, H., T. Shirahata, and K. Hasegawa. 1994. Interferon- $\gamma$ production of mitogen stimulated peripheral lymphocytes in perinatal cows. J. Vet. Med. Sci. 56:735-738.

Jaffe, B. M., and H. R. Behrnam. 1974. Prostaglandins and prostaglandin metabolites. Pages 19-34 in Methods of Hormone Radioimmunoassay. B. M. Jaffe and H. R. Behrnam, ed. Academic Press, New York.

Jump, D. B., and S. D. Clarke. 1999. Regulation of gene expression by dietary fat. Annu. Rev. Nutr. 19:63-90.

Kashiwazaki, Y. 1984. Lymphocyte activities in dairy cows with special reference to outbreaks of mastitis in pre and post-partus. Jpn. J. Vet. Res. 32:101.

Kashiwazaki, Y., Y. Maede, and S. Namioka. 1985. Transformation of bovine peripheral blood lymphocytes in the perinatal period. Jpn. J. Vet. Sci. 47:337-339.

Kehrli, M. E., B. J. Nonnecke, and J. S. Roth. 1989. Alterations in bovine lymphocyte function during the periparturient period. Am. J. Vet. Res. 50:215-220.

Khalfoun, B., G. Thibault, P. Bardos, and Y. Lebranchu. 1996. Docosahexaenoic and eicosapentaenoic acids inhibit in vitro human lymphocyte-endhothelial cell adhesion. Transplantation 62:16491657.

Laforest, J. P., and G. J. King. 1992. Effect of intrauterine application of oestradiol-17 and prostaglandin E2 on the porcine oestrus cycle and uterine endocrinology. J. Reprod. Fertil. 94:381-394.

Lamming, G. E. and M. D. Royal. 2001. Ovarian hormone patterns and subfertility in dairy cows. Occ. Publ. Br. Soc. Anim. Sci. 26:105-118.

Mallard, B. A., L. C. Wagter, M. J. Ireland, and J. C. Dekkers. 1997. Effects of growth hormone, insulin-like growth factor-I, and cortisol on periparturient antibody response profiles of dairy cattle. Vet. Immunol. Immunopathol. 60:61-76.

Marshall, L. A., and P. V. Johnston. 1985. The influence of dietary essential fatty acids on rat immunocompetent cell prostaglandin synthesis and mitogen-induced blastogenesis. J. Nutr. 115:1572-1580.

Martal, J., N. Chêne, S. Camous, L. Huynh, F. Lantier, P. Hermier, R. L'Haridon, G. Charpigny, M. Charlier, and G. Chaouat. 1997. Recent developments and potentialities for reducing embryo mortality in ruminants: The role of IFN-tau and other cytokines in early pregnancy. Reprod. Fertil. Dev. 9:355-380.

Matsuo, N., K. Osada, T. Kodama, B. O. Lim, A. Nakao, K. Yamada, and M. Sugano. 1996. Effects of $\gamma$-linolenic acid and its positional isomer pinolenic acid on immune parameters of Brown Norway rats. Prostaglandins Leukot. Essent. Fatty Acids. 55:223-229.

Mattos R., C. R. Staples, and W. W. Thatcher. 2000. Effects of dietary fatty acids on reproduction in ruminants. Rev. Reprod. 5:38-45.

Miles, E. A., and P. C. Calder. 1998. Modulation of immune function by dietary fatty acids. Proc. Nutr. Soc. 57:277-292.

National Research Council. 1989. Nutrient Requirements of Dairy Cattle. 6th rev. ed. Nat. Acad. Press, Washington, DC.
Petit, H. V., R. J. Dewhurst, J. G. Proulx, M. Khalid, W. Haresign, and H. Twagiramungu. 2001. Milk production, milk composition, and reproductive function of dairy cows fed different fats. Can. J. Anim. Sci. 81:263-271.

Petit, H. V. 2002. Digestion, milk production, milk composition, and blood composition of dairy cows fed whole flaxseed. J. Dairy Sci. 85:1482-1490.

Petit, H. V., and H. Twagiramungu. 2002. Reproduction of dairy cows fed flaxseed, Megalac or micronized soybeans. J. Anim. Sci. 80 (Suppl. 1):312. (Abstr.)

Petit, H. V., R. J. Dewhurst, N. D. Scollan, J. G. Proulx, M. Khalid, W. Haresign, H. Twagiramungu, and G. E. Mann. 2002. Milk production and composition, ovarian function, and prostaglandin secretion of dairy cows fed omega-3 fats. J. Dairy Sci. 85:889-899.

Piccinni, M. P., M. G. Giudizi, R. Biagiotti, L. Beloni, L. Giannarini, S. Sampognaro, P. Parronchi, R. Manetti, F. Annunziato, and C. Livi. 1995. Progesterone favors the development of human T helper cells producing Th2-type cytokines and promotes both IL4 production and membrane CD30 expression in established Th1 cell clones. J. Immunol. 155:128-133.

Purasiri, P., A. Mckechnie, S. D. Heys, and O. Eremin. 1997. Modulation in vitro of human natural cytotoxicity, lymphocyte proliferative response to mitogens and cytokine production by essential fatty acids. Immunology 92:166-172.

Raghupathy, R. 1997. Th1-type immunity is incompatible with successful pregnancy. Immunol. Today 18:478-482.

SAS User's Guide: Statistics, Version 8 Edition. 2000. SAS Inst., Inc., Cary, NC.

Sordillo, L. M., G. M. Pighetti, and M. R. Davis, 1995. Enhanced production of bovine tumor necrosis factor- $\alpha$ during the periparturient period. Vet. Immunol. Immunopathol. 49:263-270.

Staples, C. R., M. C. Wiltbank, R. R. Grummer, J. Guenther, R. Sartori, F. J. Diaz, S. Bertics, R Mattos, and W. W. Thatcher. 2000. Effect of long chain fatty acids on lactation performance and reproductive tissues of Holstein cows. J.Anim. Sci. 78: Suppl. 1:278. (Abstr.)

Thatcher, W. W., C. R. Staples, G. Danet-Desnoyers, B. Oldick, and E. P. Schmitt. 1994. Embryo health and mortality in sheep and cattle. J. Anim. Sci. 72 (Suppl. 3):16. (Abstr.)

Vacchio, M. S., and S-P. Jiang. 1999. The fetus and the materna immune system: pregnancy as a model to study peripheral T-cell tolerance. Crit. Rev. Immunol. 19:461-480.

Wander, R. C., J. A. Hall, J. L. Gradin, S. H. Du, and D. E. Jewell. 1997. The ratio of dietary (n-6) to (n-3) fatty acids influences immune system function, eicosanoid metabolism, lipid peroxidation and vitamin E status in aged dogs. J. Nutr. 127:1198-1205.

Wells, P. W., C. Burrells, and W. B. Martin. 1977. Reduced mitogenic responses in cultures of lymphocytes from newly calved cows. Clin. Exp. Immunol. 29: 159-161.

Yaqoob, P., and P .C. Calder. 1995. The effect of dietary lipid manipulation on the production of murine T-cell-derived cytokines. Сytokine 7:548-553. 